\title{
The Canadian general surgery resident: defining current challenges for surgical leadership
}

\author{
CoreyTomlinson, BEd, MD* \\ Joseph LaBossière, BSc, MD* \\ Kenton Rommens, BSc, MD* \\ Daniel W. Birch, MSc, MD ${ }^{\dagger}$
}

From the *Department of Surgery, University of Alberta, and the TDivision of General Surgery, Royal Alexandra Hospital, Edmonton, Alta.

Accepted for publication

Dec. 9, 2011

\author{
Correspondence to: \\ D.W. Birch \\ Room 504, Community Services Centre \\ Royal Alexandra Hospital \\ 10240 Kingsway Ave. \\ Edmonton, $\mathrm{AB}$ T5H $3 \mathrm{~V} 9$ \\ dbirch@ualberta.ca
}

DOI: $10.1503 /$ cjs.026811

\begin{abstract}
Background: Surgery training programs in Canada and the United States have recognized the need to modify current models of training and education. The shifting demographic of surgery trainees, lifestyle issues and an increased trend toward subspecialization are the major influences. To guide these important educational initiatives, a contemporary profile of Canadian general surgery residents and their impressions of training in Canada is required.
\end{abstract}

Methods: We developed and distributed a questionnaire to residents in each Canadian general surgery training program, and residents responded during dedicated teaching time.

Results: In all, 186 surveys were returned for analysis (62\% response rate). The average age of Canadian general surgery residents is 30 years, $38 \%$ are women, $41 \%$ are married, $18 \%$ have dependants younger than 18 years and $41 \%$ plan to add to or start a family during residency. Most $(87 \%)$ residents plan to pursue postgraduate education. On completion of training, $74 \%$ of residents plan to stay in Canada and $49 \%$ want to practice in an academic setting. Almost half ( $42 \%)$ of residents identify a poor balance between work and personal life during residency. Forty-seven percent of respondents have appropriate access to mentorship, whereas $37 \%$ describe suitable access to career guidance and $40 \%$ identify the availability of appropriate social supports. Just over half $(54 \%)$ believe the stress level during residency is manageable.

Conclusion: This survey provides a profile of contemporary Canadian general surgery residents. Important challenges within the residency system are identified. Program directors and chairs of surgery are encouraged to recognize these challenges and intervene where appropriate.

Contexte : Les programmes de formation en chirurgie au Canada et aux États-Unis ont reconnu qu'il fallait modifier les modèles actuels de formation et d'éducation. La démographie changeante des étudiants en chirurgie, des enjeux liés aux habitudes de vie et une tendance accrue à la surspécialisation constituent les principaux facteurs d'influence. Pour guider ces initiatives d'éducation importantes, il s'impose de dresser un profil moderne des médecins résidents en chirurgie générale au Canada et de leurs impressions au sujet de la formation au Canada.

Méthodes : Nous avons créé et distribué un questionnaire aux médecins résidents de chaque programme canadien de formation en chirurgie générale. Les médecins résidents ont répondu au cours d'une période réservée à l'enseignement.

Résultats : Au total, 186 questionnaires ont été renvoyés pour analyse (taux de réponse de $62 \%$ ). Les médecins résidents en chirurgie générale au Canada ont en moyenne 30 ans, $38 \%$ sont des femmes, $41 \%$ sont mariés, $18 \%$ ont des personnes à charge de moins de 18 ans et $41 \%$ prévoient commencer une famille ou augmenter la leur au cours de la résidence. La plupart $(87 \%)$ des médecins résidents prévoient poursuivre des études postdoctorales. Une fois leur formation terminée, 74 \% des médecins résidents prévoient demeurer au Canada et $49 \%$ veulent exercer en milieu universitaire. Presque la moité $(42 \%)$ des médecins résidents mentionnent que l'équilibre entre le travail et la vie personnelle est médiocre au cours de la résidence. Quarante-sept pourcent des répondants ont un accès approprié à des mentors tandis que $37 \%$ indiquent qu'ils ont un accès convenable à des services d'orientation professionnelle; $40 \%$ indiquent que des moyens appropriés de soutien social sont disponibles. Un peu plus de la moitié (54\%) croient que le niveau de stress au cours de la résidence est gérable.

Conclusion : Ce sondage présente un profil des médecins résidents en chirurgie générale au Canada. Des défis importants dans le système de formation en résidence sont définis. On encourage les directeurs de programme et les titulaires de chaire de chirurgie à reconnaître ces défis et à intervenir au besoin. 
rair raining surgeons capable of independent practice within a limited timeframe is the goal of surgical residency. Increasingly, surgical training programs in Canada and the United States have recognized the need to modify current training models. Forces driving the need for change include economic factors, changing demographic characteristics of trainees, lifestyle issues, the trend toward subspecialization and inefficiencies in current systems.

Historically, the mantra for surgical training was "see one, do one, teach one." Scores of surgeons were trained with this educational methodology, and today many continue to practise with this style of tutorship. This timehonoured model has avoided evolution and innovation for the past 75 years, but is now experiencing considerable strain. ${ }^{1-3}$ Surgical training is built on a strong foundation of didactic learning, reading, observation, training under close supervision and repetition, ${ }^{2}$ with the ultimate goal of having the trainee perform independently.

Despite increasing acknowledgement that major reforms are needed in surgical education, to our knowledge there have been no studies that profile the contemporary Canadian surgical trainee. The goals of the present study are to provide insight into the demographic characteristics of Canadian surgical residents and to analyze their perspective on current approaches to teaching and training. Our results could stimulate additional focused research and invite a reevaluation of current training methods of Canadian general surgeons to ensure the positive growth of our profession.

\section{Methods}

\section{Survey instrument}

Evaluation of resident surgical training was done with the administration of a survey questionnaire. The survey was validated using a comprehensive, multistage method. ${ }^{4}$ Initially, 3 brainstorming focus groups with in-depth interviews were held with medical students, general surgery residents and practising surgeons. These focus groups identified important elements of surgical education to be included into the study and ensured content validity. Following these preliminary meetings, a survey was drafted and piloted to small groups of residents and students to ensure the formatting was appropriate and easy to navigate. The survey was then reviewed at the Centre for Research in Applied Management and Evaluation (CRAME), which is a department of educational psychology at the University of Alberta. The survey was reviewed for content, format, design and wording to ensure the questions would not cause biased results.

\section{Study design}

Following survey construction, our team approached the Canadian Program Directors' Committee, seeking per- mission to submit the survey to surgical residents across the country. The survey was submitted to this committee for review, and further amendments were made, adding to the validity. Subsequently, general surgery program assistants (PAs) across Canada were contacted by email or telephone to assist in the facilitation and distribution of the survey instrument. Attempts were made to involve every teaching institution in Canada; however, some programs declined participation. The PAs at the involved institutions were instructed to promote the completion of the questionnaire during dedicated teaching time. The involvement of the PAs enabled our team to communicate the goals of the study through an unbiased liaison. These "site leaders" were contacted by phone and were provided with the necessary study information. Each site leader was compensated for their efforts with a $\$ 25.00$ gift certificate. The site leaders accepted responsibility for obtaining consent, answering questions and administering the survey.

A package of printed consent forms and surveys were mailed to each PA. Two weeks were allowed for delivery, and a reminder email was subsequently sent to the PA to address questions and stimulate a speedy response. Once completed, surveys were returned to our team in a prepaid envelope, ensuring no unintentional bias was introduced.

\section{Statistical analysis}

Residents received a 21-item survey with 12 demographic items and 9 items addressing areas of curriculum, education, teaching and general quality of life. Where appropriate, respondents answered questions on a 5 -point Likert scale. We chose a 5 -point system to mitigate respondent ambivalence to the questions. Participants were able to abstain from any question without penalty or exclusion from the study. Results for all questions were summarized and stored in a database created by the study team. Answers from the 5-point Likert scale were collapsed into 3 categories (strongly disagree and disagree, neutral, and strongly agree and agree). Data were then analyzed with descriptive statistics.

\section{Results}

\section{Demographic characteristics}

In all, 300 paper-based surveys were distributed to general surgery residents across Canada, with a $62 \%(n=186)$ response rate. Table 1 summarizes the demographic characteristics of the respondents. A breakdown of the postgraduate year (PGY) level of the respondents is presented in Figure 1. Of the 186 residents surveyed, 41\% $(n=76)$ were married, $18 \%(n=34)$ had children under the age of 18 years, and during their training $41 \%(n=77)$ wanted to start or add to their families. Of the 70 women surveyed, $34 \%(n=24)$ anticipated having children during residency. 


\section{Career aspirations}

With respect to education before residency; $10 \%$ ( $n=19$ of 182) of respondents have a Master's degree and $1 \%(n=2$ of 182$)$ have a PhD. In all, 87\% ( $n=162$ of 186$)$ of residents identified a desire to pursue postgraduate education in the form of a Master's degree, $\mathrm{PhD}$ or fellowship. Of these, $34 \%$ ( $n=55$ of 161) identified a desire to complete both a postgraduate degree and a fellowship after their general surgery training. In all, $75 \%$ ( $n=138$ of 184$)$ of respondents wanted to remain in Canada to practise; of these $53 \%$ $(n=73$ of 138$)$ wanted to remain in the province of their residency training and $36 \%(n=50$ of 138) preferred to relocate to another Canadian province. In all 18\% $(n=34$ of 184) were considering an international surgical practice.

In all, $48 \%$ ( $n=87$ of 182$)$ of respondents planned to practise in an academic setting, $43 \%(n=78$ of 182$)$ planned to work in a community setting of more than 100000 people, and 5\% ( $n=9$ of 182) planned to work in a community setting of fewer than 100000 people.

\section{Teaching}

It was a daily occurrence for $70 \%(n=126$ of 181$)$ of residents to perform a skill or procedure under direct supervision. Similarly, the observation of a skill or procedure happened daily for $81 \%(n=147$ of 181$)$ of residents. Didactic teaching is a weekly occurrence for surgical residents. The direct teaching of skills, use of cadaveric mod-

Table 1. Resident demographic charactersitics*

\begin{tabular}{|c|c|}
\hline Characteristic & No (\%) respondents, $n=186$ \\
\hline \multicolumn{2}{|l|}{ Age, yr } \\
\hline$<24$ & $5 \quad(2.7)$ \\
\hline $25-29$ & $97(52.2)$ \\
\hline $30-34$ & $64(34.4)$ \\
\hline $35-40$ & $17(9.1)$ \\
\hline$>40$ & $2(1.1)$ \\
\hline \multicolumn{2}{|l|}{ Sex } \\
\hline Male & $116(62.4)$ \\
\hline Female & 70 (37.6) \\
\hline \multicolumn{2}{|c|}{ Postgraduate year (PGY) } \\
\hline PGY-1 & 35 (18.8) \\
\hline PGY-2 & $48(25.8)$ \\
\hline PGY-3 & $41(22.0)$ \\
\hline PGY-4 & $33(17.7)$ \\
\hline PGY-5 or higher & $29(15.6)$ \\
\hline \multicolumn{2}{|c|}{ Marital status and children } \\
\hline Married & $76(40.9)$ \\
\hline Have children & $34(18.3)$ \\
\hline \multicolumn{2}{|c|}{ Wanting children in residency } \\
\hline Total, $n=186$ & $77(41.4)$ \\
\hline Women, $n=70$ & $24(34.3)$ \\
\hline Men, $n=116$ & $53(45.7)$ \\
\hline $\begin{array}{l}\text { *Some respondents d } \\
\text { demographic characte } \\
\text { reflect the total numbe }\end{array}$ & $\begin{array}{l}\text { rall questions pertaining to } \\
\text { mbers and percentages may not } \\
\text { included in our analysis. }\end{array}$ \\
\hline
\end{tabular}

els and simulation, and attending journal clubs are sporadic and occur monthly, if not yearly, at programs across the country. Problem-based learning (PBL) sessions and cadaveric modelling are not part of the teaching curriculum at 8 institutions (Fig. 2).

Residents ranked teaching methods in order from their most preferred to their least preferred method. Most residents $(81 \%, n=149$ of 184$)$ preferred performing a skill or procedure under supervision. This method was followed in order by observing a skill or procedure, direct teaching of skills, use of simulators, PBL, didactic teaching, cadaveric models and journal clubs.

The time allocation dedicated to various teaching methods is depicted in Figure 3 and demonstrates that residents want more time allocated to didactic teaching sessions, directed skills training, cadaveric modelling, simulation, PBL and performing/observing a skill or procedure. On the other hand, it appears that residents feel the teaching time dedicated to observing a skill or procedure and to journal clubs is about right.

Although intimidation was identified as a factor that interfered with learning by performing a skill or procedure, intimidation did not appear to hinder learning by other teaching methods (Fig. 4).

\section{Satisfaction with educational experience}

Overall, $25 \%$ of residents ( $n=45$ of 180$)$ were either poorly or fairly satisfied with their educational experience, whereas $49 \%$ ( $n=89$ of 180$)$ indicated a level of satisfaction that was good or excellent. With respect to the overall effectiveness of the teaching across institutions, $26 \%$ $(n=46$ of 180$)$ of respondents were either poorly or fairly satisfied, whereas $46 \%$ ( $n=83$ of 180$)$ described the effectiveness as either good or excellent. With respect to the overall quality of the teaching across institutions, $18 \%$

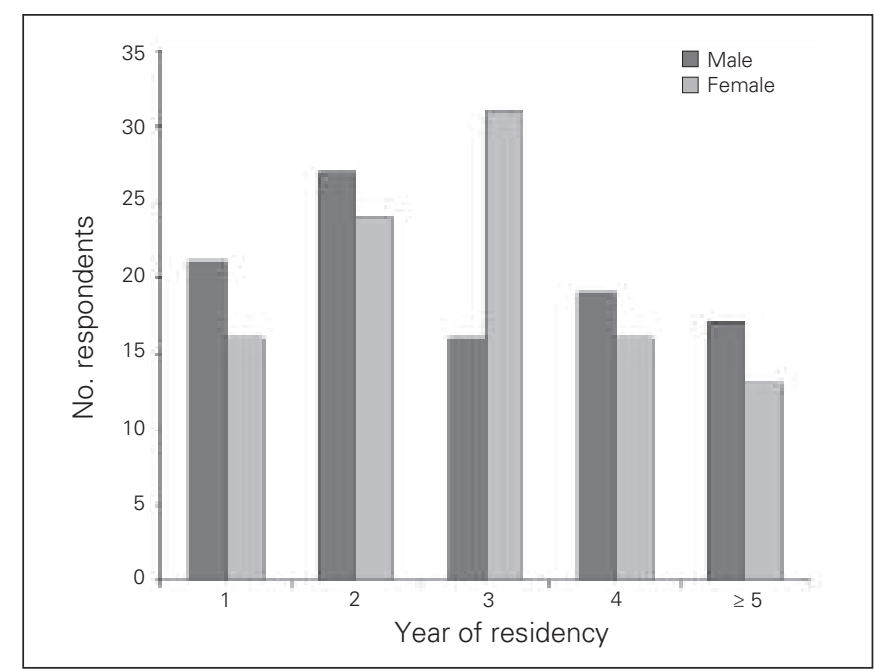

Fig. 1. A breakdown of respondents according to postgraduate level and sex. 


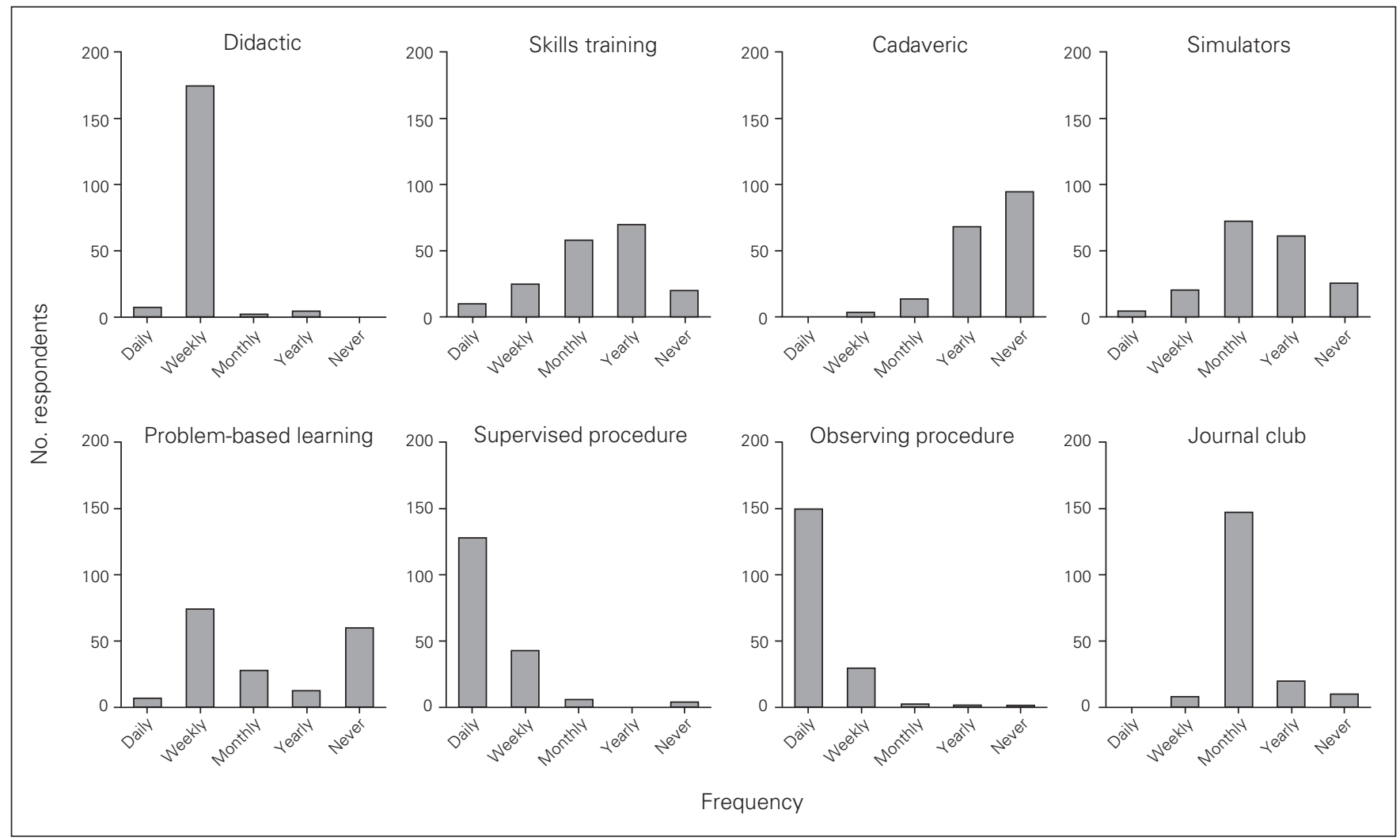

Fig. 2. The frequency of which Canadian residents are taught using different teaching modalities.

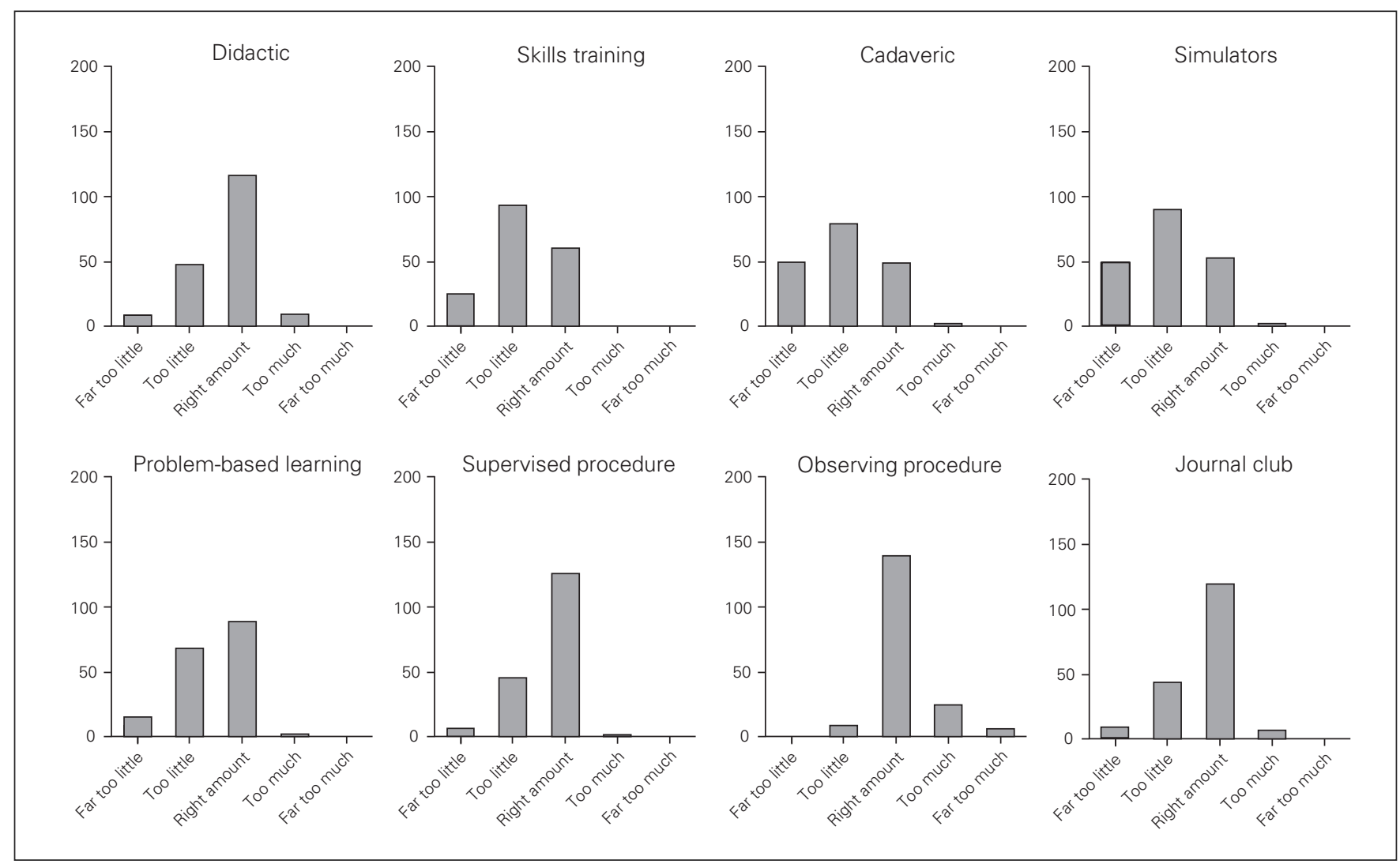

Fig. 3. Resident assessment of time spent learning, by teaching modality. 
$(n=33$ of 180$)$ of the residents were either poorly or fairly satisfied, whereas 54\% ( $n=97$ of 180) of residents felt the overall quality of teaching was good or excellent.

\section{Work and personal issues}

Regarding on-call experience, $66 \%$ of respondents $(n=122$ of 186) believed that 5-6 call shifts per month would be an equal balance of education and service, $22 \%(n=41$ of 186$)$ believed that more than 6 call shifts per month would be an ideal balance, whereas $11 \%(n=21$ of 186$)$ felt that $3-$ 4 call shiftsper month would be preferred. When questioned about salary, 70\% $(n=128$ of 182$)$ of respondents believed that, for their PGY level, they would be content with a salary greater than $\$ 65000$. In all, $42 \%(n=77$ of 183) of respondents believed that they had an inadequate balance between work and their personal lives. Also, 47\% $(n=84$ of 180$)$ reported having appropriate access to mentorship during residency and $37 \%(n=66$ of 180) agreed that they had appropriate access to career guidance. Finally, $40 \%(n=72$ of 180$)$ of respondents reported having acceptable access to social support during residency. Overall, 54\% $(n=180)$ of residents agreed that the level of stress during residency was manageable (Fig. 5).

\section{Discussion}

Increasingly, surgical training programs in Canada and the United States have recognized the need to modify current models of surgical training. Forces driving this need include the changing demographic characteristics of trainees, lifestyle issues, the trend toward surgical subspecialization and inefficiencies in the current training models. Despite increasing acknowledgement that major reforms are needed in surgical education, to our knowledge there are no studies that profile the contemporary Canadian surgical trainee.

The training of a surgeon should include education in the relevant areas of basic sciences (anatomy, physiology and pathophysiology of disease), training in fundamental diagnostic skills, the development of surgical technical skills and adequate experience in patient care to create overall competence. Our goal as educators should be to identify all necessary skills and procedures of each surgical specialty and subspecialty in an effort to construct a com- prehensive, systematic and structured list of goals and objectives. This list, like all living documents, would be subject to ratification and scrutiny but would serve as a template for objective resident training, evaluation and appraisal. Our objective as educators must be to tailor training to enhance efficiency, reproducibility and success, without abandoning the primary and historical principles of our predecessors, which was to create trainees capable of performing independent operations.

The enormity of this task cannot be underestimated, and therefore the principles of curriculum design must remain at the forefront of the surgical training revolution. The educational framework outlined by the American College of Surgeons begins the construct of a curriculum with a needs assessment, which is simply defined as an appraisal of the difference between where the learner is and where the learner should ultimately be. ${ }^{6}$ Historically, expert opinion has a played the greatest role in creating surgical training requirements. The expert describes a curriculum that is then pursued by the learner with little interaction or discussion about the end objective. This strategy has put the learner in a passive role and is the preferred choice of teaching for primary school educators. Adults, however, usually act as self-directed, internally motivated and experienced students who seek specific knowledge in their chosen area of study. ${ }^{7}$ Adult learning obviates the need to move the learner from a passive role to a substantially more active role in the curricular construct.

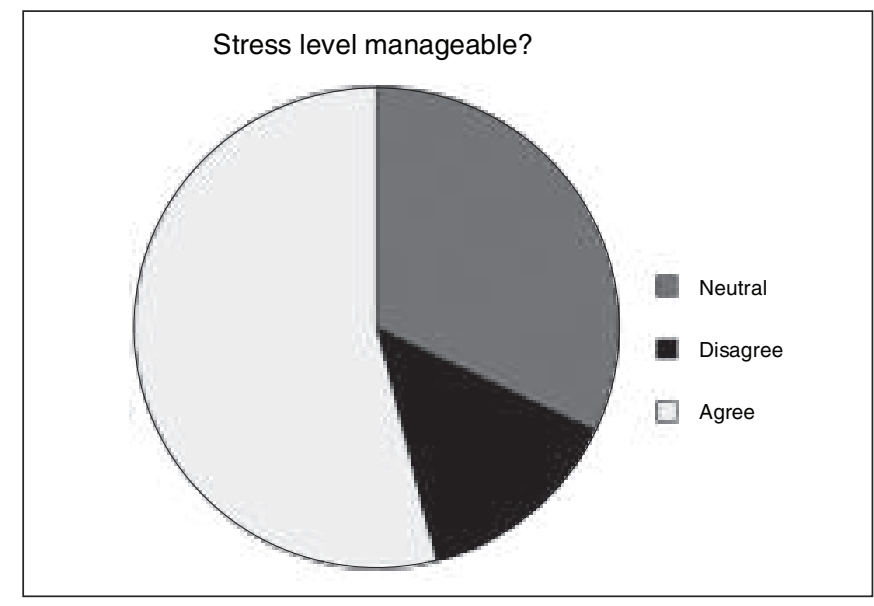

Fig. 5. Resident responses (agree, disagree or neutral) to whether the level of stress in residency is manageable.

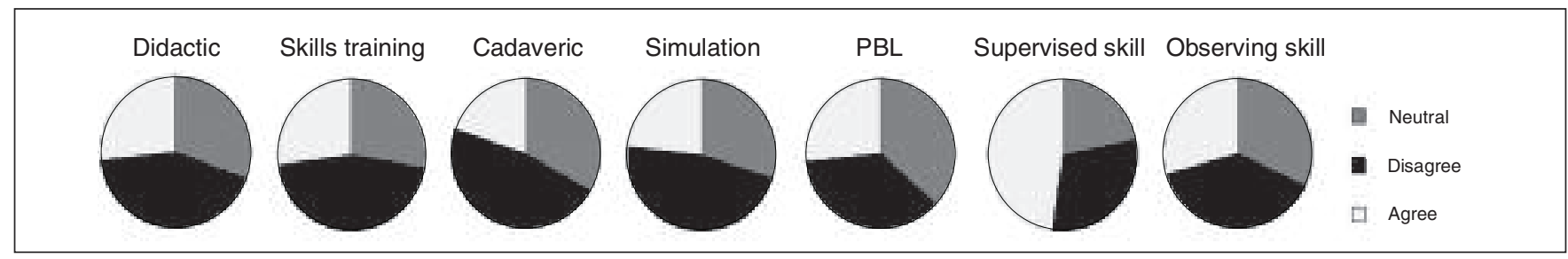

Fig. 4. Resident responses (agree, disagree or neutral) to whether intimidation interfered with their learning, by teaching method. $\mathrm{PBL}=$ problem-based learning. 
In this study, our team created a questionnaire validated with the principles of survey construction. After multiple focus groups centering on survey design, content and format, our survey was presented to CRAME. Through collaboration with this department, our team made substantial strides to incorporate the psychology of education into our delivery. After review and further modification by the Canadian program directors, the survey was ultimately distributed by the PAs of each school during academic time. The PAs were given ample opportunity to ask questions via phone and email. The response rate of $62 \%$ is owing to the efforts of the PAs. In addition, the hands-on, simple and personal approach to survey distribution, administration and collection was very effective. A web-based survey was considered, as they are cheaper, allow easier access to large populations of respondents and save time for researchers. ${ }^{7}$ When properly designed, web-based surveys also offer greater accuracy. ${ }^{8}$ When the literature was reviewed, the disadvantages of a web-based format outweighed the time, energy and cost of our more personal approach. The major issue with webbased surveys is that response rates can be up to $80 \%$ lower than those for traditional formats. ${ }^{8}$ Our fear was that the response rate would be even lower given the busy lives of residents. In addition, self-selection bias is also an issue, whereby certain individuals are more likely to respond, leading to the skewing of the results. ${ }^{7,8}$ To avoid the introduction of as much bias as possible, we elected to have residents complete the survey during dedicated academic training time. This protocol enabled all available residents the opportunity to participate and therefore assisted in minimizing selection bias.
This study demonstrates that the contemporary group of residents in general surgery in Canada is complex and diverse. The average age of the pool of respondents was 30 years, and $62 \%$ of these respondents were men. Interestingly, $41 \%$ of residents intended to start a family during their training. Almost $90 \%$ of residents intended to pursue additional postgraduate or fellowship training after their residency, which is higher rate than reported previously. ${ }^{9}$ After completion of training, $75 \%$ of trainees planned to practise surgery in Canada.

Our results propose that the current amount of time allocated to journal clubs and observing a skill/procedure meets the needs of residents. On the other hand, the time allocated to didactic teaching sessions, directed skills training, cadaveric modelling, simulation, PBL and the handson performance or observation of a skill or procedure is potentially inadequate. This is interesting considering that didactic teaching, PBL and performing a skill/procedure happen weekly, if not daily, across the country and suggests that we may need to invest more time teaching how we already teach. Our data, not surprisingly, suggest that residents want more opportunities to perform a skill or procedure with supervision versus observing that same procedure. One of the most interesting observations of this study was the need for more time to be allocated to the use of directed skills training, cadaveric models, simulation and PBL sessions. In addition, although many residents identified attending journal clubs to be their least preferred method of teaching, the data suggest that time spent learning with this method is appropriate.

Table 2. Summary of key points of interest for this project

\begin{tabular}{|c|c|}
\hline Challenge to resident success & Recommendations for surgical leadership and trainees \\
\hline $\begin{array}{l}\text { Balancing professional and } \\
\text { personal life }\end{array}$ & $\begin{array}{l}\text { 1. Plan educational learning opportunities during working hours } \\
\text { 2. Incorporate seminars on time management into curriculum } \\
\text { 3. Enhance camaraderie by promoting personal health, family, collegiality and professionalism } \\
\text { 4. Consult mentors early and often }\end{array}$ \\
\hline $\begin{array}{l}\text { Career counselling and business } \\
\text { training }\end{array}$ & $\begin{array}{l}\text { 1. Build professional seminars on recruitment and business preparation into curriculum } \\
\text { 2. Provide forums to discuss opening, running and maintaining a functioning office }\end{array}$ \\
\hline Stress management & $\begin{array}{l}\text { 1. Add stress management seminars into curriculum } \\
\text { 2. Speak candidly about work-life balance, anhedonia and depressive symptoms }{ }^{19} \\
\text { 3. Provide support to the working parent } \\
\text { 4. Ask for "time" when it is required } \\
\text { 5. Avoid keeping stress to oneself }{ }^{20}\end{array}$ \\
\hline $\begin{array}{l}\text { Evolution of the educational } \\
\text { curriculum }\end{array}$ & $\begin{array}{l}\text { 1. Develop educational retreats and resident research days } \\
\text { 2. Invite and embrace external reviews } \\
\text { 3. Reinvent curriculum to include PBL sessions, simulation, skills training and cadaveric modelling, while revisiting the } \\
\text { frequency and content of journal clubs } \\
\text { 4. Provide professional and structured feedback } \\
\text { 5. Emphasize attendance by all residents at curricular events }\end{array}$ \\
\hline Surgical training & $\begin{array}{l}\text { 1. Add routine skills training, simulation, cadaveric models and PBL sessions into surgical curriculum } \\
\text { 2. Continue to improve and emphasize the importance of didactic teaching } \\
\text { 3. Place residents in positions to "do more" and "watch less" } \\
\text { 4. Encourage staff involvement to increase } 1: 1 \text { observation/teaching }\end{array}$ \\
\hline Intimidation & $\begin{array}{l}\text { 1. Provide a positive learning environment }{ }^{21} \\
\text { 2. Increase } 1: 1 \text { teaching and tailored education for residents perceived to be struggling } \\
\text { 3. Provide an open door policy to discuss abuse, harassment }{ }^{22} \text { and intimidation }\end{array}$ \\
\hline
\end{tabular}


Our study has identified certain areas of concern. Typically, surgeons work long hours, deal regularly with life and death situations and make substantial personal sacrifices to practise in their chosen field. ${ }^{10}$ Not surprisingly, resident burnout and psychiatric morbidity has previously been correlated with long working hours; conflict between the commitments of work and home life; discord with faculty, nursing staff and senior residents; debt load; and workrelated stress. ${ }^{11}$ Signs and symptoms of burnout include physical exhaustion, poor judgment, cynicism, guilt, ineffectiveness and a sense of depersonalization in relationships. ${ }^{12,13}$ We have identified that overall levels of stress are manageable for only about half of Canadian general surgery residents. In addition to excessive levels of stress, there also appear to be deficiencies associated with balancing the responsibilities of work with the necessary activities of life. Considering that more than $40 \%$ of residents planned on starting a family while training and that only $40 \%$ of residents reported having adequate social supports, concerns with resident stress and lifestyle will continue to be an issue and must be addressed. Interestingly, Canadian residents ${ }^{14,15}$ are not alone in their feelings, as residents from around the world experience a disproportionate amount of stress and experience a disparity in work-life balance. ${ }^{16}$ In addition to resident stress, our team identified that access to mentorship and career guidance may not be adequate. Resident work-hour restrictions may mitigate these concerns; however, this should not divert attention from this important issue. In fact, despite mandated workhour reductions, 1 in 5 residents resigns from general surgery ${ }^{17}$ owing to the need to urgently intervene in areas of social support, mentorship, career guidance and stress management. Of note, resident burnout may be managed by protective factors, such as being a parent, spending time with a spouse, having a physician parent and deriving satisfaction from discussing concerns with colleagues, friends and family. ${ }^{11}$ We have developed recommendations for faculty, educators and residents that may begin to manage some of these challenges during residency (Table 2).

Our study has explored the concerns raised by Canadian general surgery residents. Issues pertaining to intimidation, burnout, attrition, teaching and resident satisfaction have been identified, and a renewed emphasis on these topics must be undertaken at the local, regional and national level. The overriding goals for this project are to provide insight into sources of success and discontent regarding the training of Canadian general surgery residents, stimulate additional focused research and invite a re-evaluation of current training methods to ensure the healthy growth of our profession.

Competing interests: None declared for C. Tomlinson, J. LaBossière and K. Rommens. D.W. Birch declares having consulted for Johnson \& Johnson/Ethicon Endo-Surgery and Covidien.

Contributors: C. Tomlinson and D.W. Birch designed the study and reviewed the article. C. Tomlinson, K. Rommens and J. LaBossière acquired the data, which C. Tomlinson, K. Rommens and D.W. Birch analyzed. All authors wrote the article and approved its publication.

\section{References}

1. Bell RH Jr, Banker MB, Rhodes RS, et al. Graduate medical education in surgery in the United States. Surg Clin North Am 2007;87:811-23, v-vi.

2. Gorman PJ, Meier AH, Rawn C, et al. The future of medical education is no longer blood and guts, it is bits and bytes. Am 7 Surg 2000; 180:353-6.

3. Longo WE. Attrition: our biggest continuing challenge. Am 7 Surg 2007;194:567-75.

4. Krause N. A comprehensive strategy for developing closed-ended survey items for use in studies of older adults. 7 Gerontol B Psychol Sci Soc Sci 2002;57:S263-74.

5. Sawyers JL. Presidential address. Graduate surgical education. $A m$ Surg 1981;47:1-5.

6. Potts JR 3rd. Core training in surgery: What does it need to include? Semin Vasc Surg 2006;19:210-3.

7. Wright KB. Researching Internet-based populations: advantages and disadvantages of online survey research, online questionnaire authoring software packages, and web survey services. 7 Comput Mediat Commun 2005;10:article 11.

8. Morrel-Samuels P. Web survey's hidden hazards. Harv Bus Rev 2003; 81:16-7.

9. Borman KR, et al. Changing demographics of residents choosing fellowships: longterm data from the American Board of Surgery. $7 \mathrm{Am}$ Coll Surg 2008;206:782-8, discussion 788-9.

10. Balch CM, Shanafelt T. Combating stress and burnout in surgical practice: a review. Adv Surg 2010;44:29-47.

11. Sargent MC, Sotile W, Sotile MO, et al. Stress and coping among orthopaedic surgery residents and faculty. 7 Bone foint Surg Am 2004;86:1579-86.

12. Balch CM, Freischlag JA, Shanafelt TD. Stress and burnout among surgeons: understanding and managing the syndrome and avoiding the adverse consequences. Arch Surg 2009;144:371-6.

13. Campbell DA Jr, Sonnad SS, Eckhauser FE, et al. Burnout among American surgeons. Surgery 2001;130:696-702, discussion 702-5.

14. Cohen JS, Leung Y, Fahey M, et al. The happy docs study: a Canadian Association of Internes and Residents well-being survey examining resident physician health and satisfaction within and outside of residency training in Canada. BMC Res Notes 2008;1:105.

15. Cohen JS, Patten S. Well-being in residency training: a survey examining resident physician satisfaction both within and outside of residency training and mental health in Alberta. BMC Med Educ 2005;5:21.

16. Ogunsemi OO, Alebiosu OC, Shorunmu OT. A survey of perceived stress, intimidation, harassment and well-being of resident doctors in a Nigerian Teaching Hospital. Niger 7 Clin Pract 2010;13:183-6.

17. Yeo H, Bucholz E, Ann Sosa J, et al. A national study of attrition in general surgery training: Which residents leave and where do they go? Ann Surg 2010;252:529-34, discussion 534-6.

18. Lovell BL, Lee RT, Frank E. May I long experience the joy of healing: professional and personal wellbeing among physicians from a Canadian province. BMC Fam Pract 2009;10:18.

19. Compton MT, Frank E. Mental health concerns among Canadian physicians: results from the 2007-2008 Canadian Physician Health Study. Compr Psychiatry 2011;52:542-7.

20. Lemaire JB, Wallace JE. Not all coping strategies are created equal: a mixed methods study exploring physicians' self reported coping strategies. BMC Health Serv Res 2010;10:208.

21. Haoka T, Sasahara S, Tomotsune Y, et al. The effect of stress-related factors on mental health status among resident doctors in Japan. Med Educ 2010;44:826-34.

22. Nagata-Kobayashi S, Maeno T, Yoshizu M, et al. Universal problems during residency: abuse and harassment. Med Educ 2009;43:628-36. 